\title{
Erratum to: Methane emissions from river buffaloes fed on green fodders in relation to the nutrient intake and digestibility
}

Sonali Prusty • Madhu Mohini • Shivlal Singh Kundu • Ajay Kumar • Chander Datt

Published online: 9 August 2013

(C) Springer Science+Business Media Dordrecht 2013

Erratum to: Trop Anim Health Prod

DOI 10.1007/s11250-013-0447-7

There was an error in the title of the article

The correct title is:

Methane emissions from river buffaloes fed on green fodders in relation to the nutrient intake and digestibility

The online version of the original article can be found at http://dx.doi.org/ 10.1007/s11250-013-0447-7. 